\title{
Peranan Majelis Pengawas Notaris Daerah terhadap Pelaksanaan Kode Etik Notaris di Kabupaten Serang
}

\author{
Hasuri, Rokilah, Dwi Nurina Pitasari \\ Universitas Serang Raya (UNSERA) \\ Correspondence email: majalah.assaadah@gmail.com, Ilameidyfaihaazis@gmail.com, Dwi.nurina@gmail.com
}

\begin{abstract}
Abstrak. Peranan Majelis Pengawas sangat penting dalam membina dan mengawasi jabatan Notaris secara terus menerus mengenai perilaku diri pribadi di dalam menjalankan jabatan maupun di luar jabatannya sebagai ujung tombak untuk menjamin kepastian hukum terhadap masyarakat yang menggunakan jasa Notaris. Penegakan Kode Etik profesi Notaris merupakan salah satu cara untuk melestarikan nilai-nilai luhur didalam profesi Notaris tersebut, sehingga profesi mulia ini dalam pelaksanaannya tidak akan mengalami penurunan kualitas dan bahkan bila perlu memperoleh peningkatan kualitas dari profesi tersebut. Adapun permasalahan yang dikaji dalam penelitian ini adalah: 1) Bagaimana Peranan Majelis Pengawas Daerah Notaris terhadap Pelaksanaan Kode Etik Notaris di Kabupaten Serang? dan 2) Bagaimana Mekanisme Pelaksanaan Pengawasan Kode Etik Notaris di Kabupaten Serang?. Tujuan penelitian ini adalah untuk mengetahui peranan Majelis Pengawas Daerah terhadap pelaksanaan kode etik Notaris di Kabupaten Serang. Penelitian ini menggunakan pendekatan yuridis empiris yang digunakan untuk melihat aspek-aspek hukum dalam interaksi sosial di masyarakat. Penelitian ini bersifat deskriptif analistis, dimaksudkan untuk memberi data yang seteliti mungkin tentang suatu keadaan atau gejala-gejala lainnya. Hasil penelitian menunjukkan bahwa peranan Majelis Pengawas Notaris adalah melaksanakan pengawasan terhadap Notaris, supaya dalam menjalankan tugas jabatannya tidak menyimpang dari kewenangannya dan tidak melanggar peraturan perundang-undangan yang berlaku dan Majelis Pengawas Notaris berwenang untuk mengawasi,membina notaris sampai dengan menjatuhkan sanksi bagi Notaris yang dinyatakan melakukan pelanggaran terhadap ketentuan-ketentuan yang berlaku.
\end{abstract}

Kata kunci: Majelis Pengawas Notaris, Kode etik, Kabupaten Serang

\begin{abstract}
The role of the Supervisory Council is very important in fostering and supervising the position of a Notary on an ongoing basis regarding personal behavior in carrying out his position and outside his position as the spearhead of ensuring legal certainty for the public who uses the services of a Notary. Enforcement of the Code of Ethics for the Notary profession is one way to preserve noble values in the Notary profession, so that this noble profession in its implementation will not experience a decrease in quality and even if necessary, obtain an increase in the quality of the profession. The problems examined in this research are: 1) What is the Role of the Regional Notary Supervisory Council on the Implementation of the Notary Code of Ethics in Serang Regency? and 2) What is the Implementation Mechanism for Supervision of the Code of Ethics for Notaries in Serang Regency? The purpose of this study was to determine the role of the Regional Supervisory Council in implementing the Notary Code of Ethics in Serang Regency. This study uses an empirical juridical approach which is used to look at legal aspects of social interaction in society. This research is descriptive-analytic, intended to provide data as accurate as possible about a condition or other symptoms. The results show that the role of the Notary Supervisory Council is to supervise Notaries, so that in carrying out their duties they do not deviate from their authority and do not violate the applicable laws and regulations and the Notary Supervisory Council is authorized to supervise, foster notaries and impose sanctions on notaries who are declared. violated the applicable provisions.
\end{abstract}

Keywords: Notary Supervisory Council, Code of ethics, Serang Regency

\section{PENDAHULUAN}

Notaris sebagai pejabat umum yang berwenang membuat akta otentik dan kewenangan lainnya, seorang Notaris menjalankan fungsi sosial yang penting dalam kehidupan masyarakat pada umumnya, masyarakat dapat meminta nasehat-nasehat dan analisis hukum dari Notaris terkait isi dari akta yang telah dibuat oleh Notaris tersebut.

Notaris dalam melaksanakan tugas-tugas dan kewenangannya harus mematuhi segala ketetapan dan aturan yang telah ditetapkan di dalam Undang-undang dan peraturan-peraturan lain yang ditetapkan oleh Ikatan Notaris Indonesia. Terkadang Notaris dalam melaksanakan tugas dan kewenangannya melakukan pelanggaran terhadap ketentuan-ketentuan yang telah ditetapkan maupun diatur didalam Kode Etik Notaris, Anggaran Dasar dan Anggaran Rumah Tangga serta peraturan Undang-undang Nomor 2 Tahun 2014 perubahan atas Undang-undang Nomor 30 tahun 2004 Tentang Jabatan Notaris. diawasi dan dibina oleh Majelis Pengawas Notaris. ${ }^{1}$

Mengingat peranan dan kewenangan Notaris sangat penting dalam kehidupan masyarakat, maka setiap perilaku dan perbuatan yang dilakukan Notaris dalam menjalankan tugasnya sangatlah rentan terhadap penyalahgunaan jabatan profesinya sehingga dapat merugikan masyarakat, oleh karena itu diperlukan suatu badan yang melakukan

${ }^{1}$ Hakiki Wari Desky, Peranan Majelis Pengawas Daerah Notaris dalam Mencegah Terjadinya Perbuatan Melawan Hukum oleh Notaris di Kota Medan, (Universitas Sumatera Utara: Premise Law Jurnal) Volume 16 Tahun 2017, hlm.1-2 
pengawasan terhadap Notaris. Tujuan pengawasan dilakukan terhadap Notaris adalah untuk memenuhi persyaratanpersyaratan dan menjalankan tugasnya sesuai dengan ketentuan-ketentuan perundang-undangan berlaku untuk keamanan kepentingan masyarakat umum. ${ }^{2}$

Tugas pokok pengawasan Notaris adalah agar segala hak dan kewenangan maupun kewajiban yang diberikan kepada Notaris dalam menjalankan tugasnya sebagaimana yang diberikan oleh peraturan dasar yang bersangkutan, senantiasa dilakukan di atas jalur yang telah ditentukan bukan hanya jalur hukum tapi juga jalur moral dan etika profesi demi terjaminnya perlindungan dan kepastian hukum bagi masyarakat. ${ }^{3}$

Notaris harus senantiasa melaksanakan tugas dan jabatannya dengan amanah, jujur, seksama, mandiri dan tidak memihak. Notaris dalam menjalankan kewenangannya tidak boleh mempertimbangkan keuntungan pribadi saja, Notaris hanya boleh memberi keterangan atau pendapat yang dapat dibuktikan kebenarannya, Notaris wajib bersikap tulus ikhlas terhadap klien dan mempergunakan segala sumber keilmuwannya, apabila Notaris yang bersangkutan tidak menguasai bidang hukum tertentu dalam pembuatan akta, maka ia wajib berkonsultasi dengan rekan lain yang mempunyai keahlian dalam masalah yang sedang dihadapi, disamping itu Notaris juga wajib merahasiakan segala sesuatu yang diketahuinya tentang masalah klien karena kepercayaan yang telah diberikan kepadanya. ${ }^{4}$

Majelis Pengawas yang dibentuk oleh Menteri Hukum dan HAM ini terdiri dari unsur pemerintah, organisasi Notaris dan ahli atau akademisi. Majelis Pengawas yang dimaksud adalah Majelis Pengawas Daerah, Majelis Pengawas Wilayah dan Majelis Pengawas Pusat. Dalam pelaksanaan pengawasan Notaris ditiap daerah kabupaten/kota terdapat Majelis Pengawas Daerah Notaris. Wewenang Majelis Pengawas Notaris, salah satunya yaitu menyelenggarakan sidang untuk memeriksa adanya dugaan pelanggaran kode etik Notaris atau pelanggaran pelaksanaan jabatan Notaris. ${ }^{5}$

Peranan Majelis Pengawas Notaris adalah melaksanakan pengawasan terhadap Notaris, supaya dalam menjalankan tugas jabatannya tidak menyimpang dari kewenangannya dan tidak melanggar peraturan perundangundangan yang berlaku, disamping itu juga melakukan pengawasan, pemeriksaan dan menjatuhkan sanksi terhadap Notaris, sedangkan fungsi Majelis Pengawas Notaris adalah agar segala hak dan kewenangan maupun kewajiban yang diberikan kepada Notaris dalam menjalankan tugas jabatannya sebagaimana yang diberikan oleh peraturan perundangundangan yang berlaku, senantiasa dilakukan diatas jalur yang telah ditentukan, bukan saja jalur hukum, tetapi juga atas dasar moral dan etika demi terjaminnya perlindungan hukum dan kepastian hukum bagi pihak yang membutuhkannya. Tidak kalah penting juga peranan masyarakat untuk mengawasi dan senantiasa melaporkan tindakan Notaris yang dalam melaksanakan tugas jabatannya tidak sesuai dengan aturan hukum yang berlaku kepada Majelis Pengawas Notaris setempat. Dengan adanya laporan seperti ini dapat mengeliminasi tindakan Notaris yang tidak sesuai dengan aturan hukum pelaksanaan tugas jabatan Notaris. ${ }^{6}$

Berdasarkan latar belakang masalah di atas, maka penulis merumuskan permasalahan sebagai berikut:

a. Bagaimana Peranan Majelis Pengawas Notaris Daerah terhadap Pelaksanaan Kode Etik Notaris di Kabupaten Serang?

b. Bagaimana Mekanisme Pelaksanaan Pengawasan Kode Etik Notaris di Kabupaten Serang?

\section{METODE}

Metode pendekatan yang digunakan dalam penelitian ini adalah yuridis empiris yaitu dengan melakukan penelitian secara timbal balik antara hukum dengan lembaga non doktrinal yang bersifat empiris dalam menelaah kaidah-kaidah hukum yang berlaku di masyarakat. ${ }^{7}$ Pendekatan ini digunakan untuk melihat aspek-aspek hukum dalam interaksi sosial di masyarakat, dan berfungsi sebagai penunjang untuk mengidentifikasi dan mengklarifikasi temuan bahan nonhukum bagi keperluan penelitian atau penulisan hukum. ${ }^{8}$ Penelitian ini bersifat deskriptif analistis, dimaksudkan untuk memberi data yang seteliti mungkin tentang suatu keadaan atau gejala-gejala lainnya, karena penelitian inidiharapkan memberi gambaran secara rinci, sistematis dan menyeluruh mengenai peraturan perundangundangan yang berlaku dikaitkan dengan teori-teori hukum dan praktek pelaksanaan hukum positif.

${ }^{2}$ Abdul Hariss dan Felda Rizki Azalia, Peranan Majelis Pengawas Daerah dalam Melakukan Pengawasan terhadap Notaris Di Kota Jambi, (Jambi:Fakultas Hukum) Jurnal Lex Specialis No 22 (2015): Desember, hlm.29.

${ }^{3}$ Ibid.,

${ }^{4}$ Didit Wardio dan Lathifah Hanim, Peranan Majelis Pengawas Daerah (MPD) Terhadap Pengawasan Pelaksanaan Tugas Jabatan Notaris Di Kabupaten Sleman, (Semarang:Fakultas Hukum, Magister Notaris), Jurnal Akta, Vol 5 No 1 Maret 2018, hlm. 128 .

5 Arifani Kurnia, Peranan Majelis Pengawas Wilayah atas Penjatuhan Sanksi Terhadap Notaris yang Tidak Membacakan Akta, Jurnal Lex Renaissance, (Yogyakarta: Pascasarjana Fakultas Hukum Universitas Islam Indonesia), No. 2 Vol. 2 Juli 2017, hlm. 375.

\footnotetext{
${ }^{6}$ Ibid., hlm. 129.

${ }^{7}$ Zainuddin Ali, Sosiologi Hukum, (Jakarta: Sinar Grafika 2016), hlm.15.

${ }^{8}$ Zainuddin Ali, Metode Penelitian Hukum, (Jakarta: Sinar Grafika 2016), hlm.105.
} 
Penelitian ini mengambil lokasi di Sekretaris Daerah (Setda) Kabupaten Serang sebagai domisili Majelis Pengawas Notaris Daerah Kabupaten Serang berada. Dalam Teknik Pengumpulan Data ini menggunakan metode penelitian kepustakaan dan metode penelitian lapangan. ${ }^{9}$ Data kepustakaan yang diperoleh melalui penelitian kepustakaan yang bersumber dari peraturan perundang-undangan, buku-buku, dokumen resmi, publikasi, dan hasil penelitian. Sedangkan data lapangan yang diperlukan sebagai penunjang diperoleh melalui informasi dan pendapatpendapat dari respnden yang ditentukan secara purposive sampling (ditentukan oleh peneliti berdasarkan kemampuannya) dan/atau random sampling (ditentukan oleh peneliti secara acak). Berdasarkan sifat penelitian yang menggunakan metode penelitian bersifat deskriptif analistis, analisis data yang digunakan adalah pendekatan kualitaif terhadap data primer dan data sekunder. Deskriptif tersebut, meliputi isi dan struktur hukum posiif, yaitu suatu kegiatan yang dilakukan oleh penulis untuk menentukan isi atau makna aturan yang dijadikan rujukan dalam menyelesaikan permasalahan hukum yang menjadi objek kajian. ${ }^{10}$

\section{Kerangka Konseptual \\ Kode Etik}

Kode etik berasal dari bahasa Latin codex yang berarti kumpulan, dan ethos yang berarti kebiasaan, adat, watak, perasaan, sikap, dan cara berpikir. Jadi Kode etik dipahami sebagai norma dan peraturan mengenai etika, baik yang tertulis maupun tidak tertulis dari suatu profesi yang dinyatakan organisasi profesi. Fungsinya sebagai pengingat berperilaku bagi para anggota organisasi profesi tersebut. ${ }^{11}$

Kode etik sebagai pagar pengingat mana yang boleh dan tidak boleh yang dinamis mengikuti perkembangan lingkungan dan para pihak yang berkepentingan. Kode etik bagi para notaris hanya sampai pada tataran sanksi moral dan administratif, namun berbeda dengan spiritualitas, tataran sanksinya adalah sanksi Tuhan yang bisa langsung dirasakan di dunia (karma) maupun yang akan dibayar di akhirat kelak. Oleh karena itu Ikatan Notaris Indonesia memandang ke depan pembangunan kadar spiritualitas anggota Ikatan Notaris Indonesia akan menjadi bagian penting dari pembentukan karakter notaris Indonesia yang profesional. Ikatan Notaris Indonesia melalui Dewan kehormatan hendaknya harus dapat memastikan bahwa anggotanya memahami dengan baik dan jelas kode etik notaris itu. Dengan demikian terdapat satu kesepahaman, yang nantinya dapat menunjang penegakan kode etik bagi para anggotanya. ${ }^{12}$

\section{Pengawasan}

Kata pen gawasan berasal dari kata awas, berarti antara lain penjagaan. Istilah pengawasan dalam bahasa Inggris disebut controlling yang diterjemahkan dengan istilah pengawasan dan pengendalian. Akan tetapi di kalangan ahli atau sarjana telah disamakan pengertian controlling ini dengan pengawasan. Jadi pengawasan adalah termasuk pengendalian. ${ }^{13}$

Dalam pasal 1 angka (1) Peraturan Menteri Hukum dan Hak Asasi Manusia Republik Indonesia Nomor M.02.PR.08.10 Tahun 2004 menegaskan yang dimaksud dengan pengawasan adalah kegiatan preventif dan represif termasuk kegiatan pembinaan yang dilakukan oleh Majelis Pengawas terhadap Notaris. Sesuai juga dengan yang diatur dalam Keputusan Menteri Kehakiman dan Hak Asasi Manusia Nomor. M-O1.HT.03.01 Tahun 2003 tentang Kenotarisan yang dimaksud dengan pengawasan dalam Pasal 1 ayat (8) yaitu kegiatan administratif yang bersifat preventif dan represif oleh Menteri yang bertujuan untuk menjaga agar para Notaris dalam menjalankan jabatannya sesuai dengan peraturan perundang-undangan.

Kemudian Robert J. Mocker menyatakan definisi pengawasan sebagai berikut : "Pengawasan adalah suatu upaya yang sistematis untuk menetapkan standar prestasi pada sasaran perencanaan, merancang, sistemumpan balik informasi, membandingkan prestasi sesungguhnya dengan standar yang terlebih dahulu ditetapkan itu, menentukan apakah ada penyimpangan dan mengukur signifikansi penyimpangan tersebut, dan mengambil tindakan perbaikan yang diperlukan untuk menjamin bahwa semua sumber daya perusahaan telah di-gunakan dengan cara yang paling efektif dan efisien guna tercapainya sasaran perusahaan". ${ }^{14}$

Keputusan Menteri Hukum dan HAM Nomor. M.01.HT.03.01 Tahun 2003 tentang Kenotarisan dalam Pasal 1 ayat (8) pengawasan adalah kegiatan administratif yang bersifat preventif dan represif oleh Menteri yang bertujuan untuk menjaga agar para Notaris dalam menjalankan jabatannya sesuai dengan peraturan perundang-undangan.14 Hal

\footnotetext{
${ }^{9}$ Ibid., hlm.107.

${ }^{10}$ Ibid.,

${ }^{11}$ Herlina Ernawati Napitupulu, Peranan Ikatan Notaris Indonesia Dalam Pembinaan Notaris Dan Pengawasan Kode Etik Notaris Di Wilayah Sumatera Utara, (Medan: Universitas Sumatera Utara, Premise Law Journal), 2017, hlm.6.

12 Ibid., hlm. 7.

13 Putera Astomo, Ilmu Perundang-undangan: Teori dan Praktik di Indonesia, (Depok: Rajawali Pers, 2018), hlm.137.

${ }^{14}$ Abdul Hariss, \& Nur Fauzia, Peranan Majelis Pengawas Daerah Dalam Melakukan Pengawasan Terhadap Notaris Di Kota Jambi, (Jambi: Fakultas Hukum), Jurnal Lex Specialis No 24 (2016). hlm.90-91.
} 
yang sama juga terdapat dalam Keputusan Menteri Hukum dan HAM Nomor. M.39-PW.07.10 Tahun 2004 tentang Pedoman Pelaksanaan Tugas Majelis Pengawas Notaris, bahwa pengawasan yaitu memberikan pembinaan dan pengawasan baik secara preventif maupun kuratif kepada Notaris dalam menjalankan profesinya sebagai pejabat umum sehingga Notaris senantiasa harus meningkatkan proesionalisme dan kualitas kerjanya, sehingga dapat memberikan jaminan kepastian dan perlindungan hukum bagi penerima jasa Notaris dan masyarakat luas.

Segala bentuk pengawasan dan lembaga pengawasan terhadap Notaris muncul karena adanya kebutuhan akan penegakan etika profesi itu sendiri, dimana etika profesi tersebut berisi tentang nilai-nilai baik dan buruk, yang boleh dan tidak boleh dilakukan, dan mengenai kepatutan berkaitan dengan pelaksanaan profesi Notaris. Pelaksanaan profesi Notaris dipandang sebagai sikap hidup, yang berupa kesediaan untuk memberikan pelayanan profesional di bidang hukum terhadap masyarakat dengan keterlibatan penuh dan keahlian dalam rangka melaksanakan tugas yang berupa kewajiban terhadap masyarakat yang membutuhkan pelayanan hukum dengan disertai refleksi yang seksama, dan oleh karena itu didalam melaksanakan profesinya terdapat kaidah-kaidah pokok berupa Kode Etik profesi. ${ }^{15}$

Disamping itu pengawasan dilaksanakan karena adanya kebutuhan untuk menjaga kepercayaan dari masyarakat terhadap profesi Notaris sebagai pengguna jasa Notaris. Untuk mencapai sebuah praktek pembinaan dan pengawasan yang ideal, pada prinsipnya pembinaan dan pengawasan sangat bergantung kepada bagaimana pembinaan dan pengawasan itu dijalankan. Dengan kata lain, pelaksanaan pengawasan harus disesuaikan dengan kebutuhan dan tujuan yang hendak dicapai melalui kegiatan tersebut. Oleh karena itu, langkah-langkah yang diambil oleh Majelis Pengawas Notaris dalam melakukan pembinaan dan pengawasan haruslah dipikirkan secara cermat, dan teliti agar tepat sasaran.

\section{HASIL DAN PEMBAHASAN}

\section{Peranan Majelis Pengawas Daerah Notaris terhadap Pelaksanaan Kode Etik Notaris di Kabupaten Serang}

Dalam Undang-Undang Jabatan Notaris memiliki Majelis Pengawas Notaris. Majelis Pengawas Notaris adalah suatu badan yang mempunyai kewenangan dan kewajiban untuk melaksanakan pembinaan dan pengawasan terhadap Notaris sebagaimana diatur dalam Pasal 1 angka (6) Undang-Undang Nomor 2 Tahun 2014 tentang Perubahan atas Undang-Undang Nomor 30 Tahun 2004 tentang Jabatan Notaris.

Majelis Pengawas Notaris terdiri atas Majelis Pengawas Daerah, Majelis Pengawas Wilayah dan Majelis Pengawas Pusat yang masing-masing tingkatan terdiri dari 3 (tiga) unsur, yaitu Pemerintahan, Organisasi Notaris dan Ahli/akademisi. Tugas utama dari Majelis Pengawas Notaris juga melakukan pembinaan, pengawasan dan pemberian sanksi atas pelanggaran yang dilakukan oleh Notaris baik mengenai kode etik maupun pidana.

Majelis Pengawas Notaris berwenang untuk mengawasi, membina notaris sampai dengan menjatuhkan sanksi bagi Notaris yang dinyatakan melakukan pelanggaran terhadap ketentuan-ketentuan yang berlaku. Majelis Pengawas Notaris memiliki kewenangan tidak hanya pada pelaksanaan tugas jabatan Notaris agar sesuai dengan ketentuan Undang-Undang Jabatan Notaris, tapi juga Kode Etik Notaris. ${ }^{16}$

Pembinaan Notaris oleh Majelis Pengawas Notaris dilakukan baik sebelum dan sesudah diterima laporan dari pihak yang merasa dirugikan mengenai pelanggaran Notaris baik pelanggaran kode etik Notaris maupun jabatan Notaris, serta telah dilakukan sebelum dan sesudah diangkat sebagai Notaris. Berkaitan dengan pembinaan yang dilakukan oleh Majelis Pengawas Notaris antara lain: ${ }^{17}$

a. Sebelum diangkat sebagai Notaris; Mengadakan pelatihan persiapan Ujian Kode Etik Notaris bagi para calon Notaris.

b. Setelah menjadi Notaris: 1).Dilakukan pembinaan pada saat pemeriksaan berlangsung mengenai protokol notaris, mengenai pembuatan akta dan perlengkapan sarana kantor notaris yang diperiksa, jika belum sesuai akan diberi catatan dan tenggang waktu untuk memperbaikinya; 2). Pembinaan mengenai prilaku notaris dalam menjalankan jabatannya pada saat diperiksa atas laporan pelanggaran Notaris yang diterima oleh Majelis Pengawas Daerah.

Bagi Notaris yang melakukan pelanggaran Kode Etik,Dewan Kehormatan berkoordinasi dengan Majelis Pengawas berwenang melakukan pemeriksaan atas pelanggaran tersebut dan dapat menjatuhkan sanksi kepada pelanggarnya. Sanksi yang dikenakanterhadap anggota "Perkumpulan" yang melakukan pelanggaran Kode Etik terdapat dalamPasal 6 ayat (1) Perubahan Kode Etik Notaris Kongres Luar Biasa Ikatan Notaris Indonesia Banten tahun 2015.

15 Purwantoro dan Fatriansyah, Peran Majelis Pengawas Wilayah Notaris dan Majelis Kehormatan Notaris Terhadap Pembinaan dan Pengawasan Notaris, (Jambi:Magister Kenotariatan, Universitas Jambi), Jurnal Recital Review Vol. 1 No.2 (2019), hlm.20.

${ }^{16}$ Edelin Patricia, Sinergitas Dewan Kehormatan Notaris Dan Majelis Pengawas Notaris Dalam Pemberian Sanksi Atas Pelanggaran Kode Etik, (Program Studi Magister Kenotariatan: Fakultas Hukum Universitas Sumatera Utara), Premise Law Jurnal, Volume 7 Tahun 2019, hlm.10.

${ }^{17}$ Ibid., hlm.11-12. 
Sanksi yang dikenakan terhadap anggota melakukan pelanggaran kode etik dapat berupa: a).Teguran; b).Peringatan; c).Pemberhentian sementara dari keanggotaan Perkumpulan; d).Pemberhentian dengan hormat dari keanggotaan Perkumpulan; e). Pemberhentian dengan tidak hormat dari keanggotaan Perkumpulan. ${ }^{18}$

Selain sanksi tersebut diatas, Majelis Pengawas Notaris juga berwenang melakukan pengusulan pemecatan yang diatur dalam Pasal 77 huruf (d) Undang-Undang Nomor 30 Tahun 2004 tentang Jabatan Notaris yang menyatakan bahwa Majeli Pengawas Pusat dapat mengusulkan pemberian sanksi berupa pemberhentian tidak hormat kepada Menteri Hukum dan Hak Asasi Manusia Republik Indonesia.

\section{Mekanisme Pelaksanaan Pengawasan Kode Etik Notaris di Kabupaten Serang}

Pengawasan Notaris melalui mekanisme pemeriksaan dapat dibedakan menjadi 2 (dua) yaitu: ${ }^{19}$

1. Pemeriksaan setiap waktu (berkala) dan pemeriksaan yang dianggap perlu; dan

2. Pemeriksaan karena ada pengaduan masyarakat karena adanya dugaan pelanggaran koda etik notaris atau dugaan melanggar jabatan notaris, atau adanya permintaan dari pihak penyidik, kejaksaan atau dari hakim yang sedang memeriksa suatu perkara yang ada sangkut pautnya dengan notaris.

Jika ada pihak yang merasa dirugikan, karena adanya dugaan pelanggaran kode etik atau pelanggaran jabatan notaris, dapat mengajukan laporan secara tertulis kepada Majelis Pengawas Daerah Kabupaten Serang. Laporan dimaksud segera akan ditindaklanjuti yang diawali dengan dimana Ketua Majelis Pengawas Daerah Kabupaten Serang membentuk Majelis Pemeriksa, yang berjumlah 3 orang yang diambil dari masing-masing unsur Majelis Pengawas Daerah, dan dibantu oleh seorang sekretaris. Namun dalam hal ini Majelis Pemeriksa tidak berwenang menjatuhkan sanksi terhadap notaris terlapor. Majelis Pemeriksa Wilayah dan Majelis Pemeriksa Pusat berwenang memeriksa dan memutus laporan yang diterima. Pemeriksaan oleh Majelis Pemeriksa Daerah meliputi: ${ }^{20}$

a. Laporan pengaduan masyarakat;

b. Pemeriksaan Protokol Notaris; dan/atau

c. Fakta hukum terhadap dugaan pelanggaran pelaksanaan jabatan dan perilaku Notaris.

Majelis Pengawas dalam melakukan pemeriksaan terhadap dugaan pelanggaran perilaku dan pelaksanaan jabatan Notaris membentuk Majelis Pemeriksa. Majelis Pemeriksa berjumlah 3 (tiga) orang yang trdiri dari 1 (satu) orang ketua; dan 2 (dua) orang anggota dibantu oleh 1 (satu) orang sekretaris. Pembentukan Majelis Pemeriksa dilakukan paling lama 14 (empat belas) Hari terhitung sejak: a.Laporan pengaduan masyarakat kepada Majelis Pengawas Daerah; b. hasil rekomendasi pemeriksaan Majelis Pengawas Daerah kepada Majelis Pengawas Wilayah; atau $\mathrm{c}$.permohonan banding atas putusan Majelis Pengawas Wilayah kepada Majelis Pengawas Pusat,diterima dan diregister.

Pemeriksaan oleh Majelis Pemeriksa Daerah bersifat tertutup untuk umum dan dimulai paling lama 7 (tujuh) Hari sejak Majelis Pemeriksa ditetapkan. Majelis Pemeriksa Daerah menyelesaikan dan menyampaikan hasil pemeriksaan paling lama 30 (tiga puluh) Hari terhitung sejak Laporan dicatat di buku register perkara.

Tata cara pemeriksaan oleh Pengawas notaris daerah Kabupaten Serang sesuai dengan Peraturan Menteri Hukum Dan Hak Asasi Manusia Republik Indonesia Nomor 15 Tahun 2020 tentang Tata Cara Pemeriksaan Majelis Pengawas Terhadap Notaris adalah: 1) Pemeriksaan dilakukan dengan cara memanggil Pelapor dan Terlapor. 2) Pemeriksaan meliputi:a.kehadiran Pelapor dan Terlapor; b.pembacaan Laporan dan keterangan Pelapor; dan c.pembelaan diri Terlapor. 3) Dalam pemeriksaan Pelapor dan Terlapor diberi kesempatan untuk menyampaikan tanggapan. 4) Dalam menyampaikan tanggapan Pelapor dan Terlapor dapat mengajukan bukti untuk mendukung dalil yang diajukan. Hasil pemeriksaan dituangkan dalam berita acara pemeriksaan dan rekomendasi hasil pemeriksaan.

Pemeriksaan Protokol Notaris dilaksanakan berdasarkan hasil pemeriksaan berkala 1 (satu) kali dalam 1 (satu) tahun atau setiap waktu yang dianggap perlu. Hasil pemeriksaan berupa berita acara pemeriksaan Protokol Notaris dan rekomendasi hasil pemeriksaan. ${ }^{21}$ Pemeriksaan fakta hukum terhadap dugaan pelanggaran pelaksanaan jabatan dan perilaku dilaksanakan berdasarkan putusan pengadilan yang telah mempunyai kekuatan hukum tetap dan/atau fakta

${ }^{18}$ Ibid., hlm. 12 .

19 Dewa Nyoman Rai Asmara Putra1Sagung Putri M.E Purwani, Pengawasan Notaris Oleh Majelis Pengawas Notaris Daerahpasca Putusan M.K.No. 49/Puu-X/2012, (Jurnal Magister Hukum Udayana: Denpasar, Desember 2016), Vol. 5, No. 4, hlm.797.

20 Peraturan Menteri Hukum Dan Hak Asasi Manusia Republik Indonesia Nomor 15 Tahun 2020 tentang Tata Cara Pemeriksaan Majelis Pengawas Terhadap Notaris pasal 18.

${ }^{21}$ Ibid., Pasal 21. 
hukum lainnya.Pemeriksaan dilakukan dengan memanggil Notaris yang bersangkutan untuk membela dirinya. Hasil pemeriksaan sebagaimana dituangkan dalam berita acara pemeriksaan dan rekomendasi hasil pemeriksaan. ${ }^{22}$

\section{SIMPULAN}

Dari uraian masalah tersebut di atas maka dapat disimpulkan hasil penelitian ini diantaranya yaitu:

a. Majelis Pengawas Wilayah Notaris adalah suatu lembaga yang dibentuk oleh Menteri Hukum dan Hak dan Asasi Manusia Republik Indonesia yang bertugas melakukan pengawasan terhadap Notaris. Pengawasan yang dilakukan oleh Majelis Pengawas Wilayah Notaris itu tetap harus ada karena sangat berperan dalam proses pembinaan serta pengawasan terhadap kinerja para anggotanya guna meminimalisir kekeliruan dan pelanggaran dalam menjalankan tugas jabatannya sesuai dengan kode etik.

b. Majelis Pengawas berwenang melakukan pembinaan dan pengawasan terhadap Notar is serta melakukan pemeriksaan terhadap dugaan pelanggaran perilaku dan pelaksanaan jabatan Notaris. Majelis Pemeriksa berwenang melakukan pemeriksaan yang meliputi Laporan pengaduan masyarakat; Pemeriksaan Protokol Notaris; dan/atau Fakta hukum terhadap dugaan pelanggaran pelaksanaan jabatan dan perilaku Notaris.

\section{DAFTAR PUSTAKA}

\section{Buku}

Ali, Zainuddin. Metode Penelitian Hukum, (2016), Jakarta: Sinar Grafika.

-----------, Sosiologi Hukum, (2016), Jakarta: Sinar Grafika.

Astomo, Putera. Ilmu Perundang-undangan: Teori dan Praktik di Indonesia, (2018), Depok: Rajawali Pers.

\section{Jurnal}

Abdul Hariss dan Felda Rizki Azalia, Peranan Majelis Pengawas Daerah dalam Melakukan Pengawasan terhadap Notaris Di Kota Jambi, (Jambi:Fakultas Hukum) Jurnal Lex Specialis No 22 (2015): Desember 2015.

Abdul Hariss, \& Nur Fauzia, Peranan Majelis Pengawas Daerah Dalam Melakukan Pengawasan Terhadap Notaris Di Kota Jambi, (Jambi: Fakultas Hukum), Jurnal Lex Specialis No 24 (2016). Desember 2016.

Arifani Kurnia, Peranan Majelis Pengawas Wilayah atas Penjatuhan Sanksi Terhadap Notaris yang Tidak Membacakan Akta, Jurnal Lex Renaissance, (Yogyakarta: Pascasarjana Fakultas Hukum Universitas Islam Indonesia), No. 2 Vol. 2 Juli 2017.

Dewa Nyoman Rai Asmara Putra1Sagung Putri M.E Purwani, Pengawasan Notaris Oleh Majelis Pengawas Notaris Daerahpasca Putusan M.K.No. 49/Puu-X/2012, (Jurnal Magister Hukum Udayana: Denpasar, Desember 2016), Vol. 5, No. 4.

Didit Wardio dan Lathifah Hanim, Peranan Majelis Pengawas Daerah (MPD) Terhadap Pengawasan Pelaksanaan Tugas Jabatan Notaris Di Kabupaten Sleman, (Semarang:Fakultas Hukum, Magister Notaris), Jurnal Akta, Vol 5 No 1 Maret 2018.

Edelin Patricia, Sinergitas Dewan Kehormatan Notaris Dan Majelis Pengawas Notaris Dalam Pemberian Sanksi Atas Pelanggaran Kode Etik, (Program Studi Magister Kenotariatan: Fakultas Hukum Universitas Sumatera Utara), Premise Law Jurnal, Volume 7 Tahun 2019.

Hakiki Wari Desky, Peranan Majelis Pengawas Daerah Notaris dalam Mencegah Terjadinya Perbuatan Melawan Hukum oleh Notaris di Kota Medan, (Universitas Sumatera Utara: Premise Law Jurnal) Volume 16 Tahun 2017.

Herlina Ernawati Napitupulu, Peranan Ikatan Notaris Indonesia Dalam Pembinaan Notaris Dan Pengawasan Kode Etik Notaris Di Wilayah Sumatera Utara, (Medan: Universitas Sumatera Utara, Premise Law Journal), 2017.

Purwantoro dan Fatriansyah, Peran Majelis Pengawas Wilayah Notaris dan Majelis Kehormatan Notaris Terhadap Pembinaan dan Pengawasan Notaris, (Jambi:Magister Kenotariatan, Universitas Jambi), Jurnal Recital Review Vol. 1 No.2 (2019).

\section{Peraturan Perundang-undangan}

Undang-Undang Republik Indonesia Nomor 2 Tahun 2014 Tentang Perubahan Atas Undang-Undang Nomor 30 Tahun 2004 Tentang Jabatan Notaris

Peraturan Menteri Hukum Dan Hak Asasi Manusia Republik Indonesia Nomor 15 Tahun 2020 tentang Tata Cara Pemeriksaan Majelis Pengawas Terhadap Notaris

Peraturan Menteri Hukum dan Hak Asasi Manusia Republik Indonesia Nomor : M.02. PR.08.10 Tahun 2004 tentang Tata Cara Pengangkatan Anggots, Pemberhentian Anggota, Susunan Organisasi, Tata Cara Pemeriksaan Majelis Pengawas Notaris. 
Hasuri, Rokilah dan Dwi Nurina Pitasari, Peranan Majelis Pengawas Notaris Daerah terhadap Pelaksanaan Kode Etik Notaris di Kabupaten Serang

Keputusan Menteri Hukum dan Hak Asasi Manusia Republik Indonesia Nomor : M.01-HT.03.01 Tahun 2003 tentang Kenotarisan.

Keputusan Menteri Hukum dan Hak Asasi Manusia Republik Indonesia Nomor : M.39-PW.07.10 Tahun 2004 tentang Pedoman Pelaksanaan Tugas Majelis Pengawas Notaris. 